International Journal of Business Management and Economic Review

Vol. 4, No. 04; 2021

ISSN: 2581-4664

\title{
THE EFFECT OF LEADERSHIP EFFECTIVENESS AND WORK ENVIRONMENT ON WORK PRODUCTIVITY AND ITS IMPACT ON PERFORMANCE OF INDUSTRY, TRADE, COOPERATIVE AND SMALL-MEDIUM ENTERPRISES DEPARTMENT OF PIDIE JAYA
}

\author{
Azharyadi, Said Musnadi and Hamdi Harmen \\ Management Department, Universitas Syiah Kuala, Indonesia \\ http://doi.org/10.35409/IJBMER.2021.3296
}

\begin{abstract}
This study intends to examine the effect of leadership effectiveness, work environment on work productivity, and its impact on organizational performance. The population was all employees at of the Department of Industry, Trade, Cooperatives, and Small and Medium Enterprises (Disperindagkop) Department of Pidie Jaya Regency, Indonesia, totaling 84 employees. The respondents were also all employees in the Disperindagkop environment because the population is relatively small. The data was measured using a Likert scale and the research model was analyzed using the Partial Least Square (PLS). The results of the descriptive hypotheses test show that the variables of leadership effectiveness, work environment, work productivity, and the performance of the Pidie Jaya Disperindagkopare in good condition. The results of testing the direct path hypothesis are known that leadership effectiveness significantly influences work productivity, work environment significantly influences work productivity, leadership effectiveness significantly influences organizational performance, work environment significantly influences organizational performance, and work productivity significantly influences organizational performance. The results of testing the indirect effect hypothesis (indirect path) show that work productivity partially mediates leadership effectiveness affecting organizational performance, and work productivity partially mediates work environment affecting organizational performance. Thus, the tested organizational performance improvement model can be applied, namely by increasing the effectiveness of the leadership and work environment so that it can affect the increase in work productivity and will ultimately have an impact on organizational performance. For further researchers can develop this model by adding other variables such as work performance and innovation that exist in employees in the organization.
\end{abstract}

Keyword: Leadership Effectiveness, Work Environment, Work Productivity, Organizational Performance.

\section{INTRODUCTION}

Pidie Jaya Regency, Indonesia, has high regional potential, namely in the fields of agriculture and animal husbandry, forestry and plantations, marine and fisheries, as well as industry, trade, cooperatives, and Small-Medium enterprises. In the industrial sector, one of the 


\section{International Journal of Business Management and Economic Review}

Vol. 4, No. 04; 2021

ISSN: 2581-4664

most well-known home industries in the Pidie Jaya district is "adee" cake. This "adee" cake has become the most famous regional souvenir icon in Pidie Jaya. Until now, this home industry business continues to increase. Based on the statistical data obtained, at the end of 2011, there were 16 business units with a production capacity of 30,500 units/year. Over time, this number continues to increase along with the increasing popularity of the home industry food. In addition, in Pidie Jaya Regency there is also a leather shoe and sandal industry. This business is an independent business located in Bandar Dua District. The business continues to grow due to the use of materials and the quality of materials that are maintained.

Another industry in Pidie Jaya Regency is the cocoa processing industry in Baroh Musa Village, Bandar Baru District. This chocolate processing was initiated by one of the cooperatives in Pidie Jaya Regency. The cocoa processing factory is capable of processing $10 \mathrm{~kg}$ of chocolate per day consisting of chocolate bars, various chocolate foods, and various chocolate drinks(Humas-Pidie Jaya, 2016).In the current era of digitalization, there have been many improvements in various sectors of life. The increasing number of sectors of life causes more and more people's needs that must be met. Today's modernity causes many modern markets to develop. As a public organization, the government of Pidie Jaya Regency continues to strive to be more responsive in dealing with various demands for change.

As one of the government institution within the Pidie Jaya Regency government as stipulated in Qanun No 4/2016, the Industry, Trade, Cooperatives and Small-Medium Enterprises (Disperindagkop) Department of Pidie Jaya, has the task of providing support, planning and controlling macro development, implementing market development traditional, pilot, disadvantaged areas, art markets, auction markets, and sorting warehouses, carrying out human resource development, in the fields of industry, trade, cooperatives, small and medium enterprises, mining and energy have a big role in growing and improving the community's economy.

To achieve poverty alleviation and improve community welfare, the Disperindagkop of Pidie Jaya must refer to improving quality in all sectors and creating job opportunities, especially the industrial, trade, cooperative, and Small-Medium Enterprise sectors. Therefore, the Disperindagkop of Pidie Jaya is required to work professionally in the administration of local government by trying to improve its performance. However, the overall performance of Disperindagkop is still categorized as not optimal where based on data obtained from the Central Statistics Agency of Pidie Jaya Regency, unemployment data is still very high, namely as many as 2,483 people. In addition, the poverty rate is also still very high, which is 19,309 people(Badan-Statistik, 2019).

Of course, the Disperindagkop of Pidie Jaya still really needs hard work and smart work. The success or failure of the performance of a public sector organization, especially Disperindagkop of Pidie Jaya, cannot be separated from the work productivity of the employees of the agency. Work productivity is very important for an organization, with high work productivity the work will be carried out efficiently and effectively so that the goals that have been set can be achieved(Kimsean, 2004).

High and low work productivity owned by employees is strongly influenced by many factors, ones of which is the effectiveness of leadership and work environment, which in this study these two factors are used as measuring variables in an effort to increase work productivity and organizational performance, and this study tries to link the factorson organizational 


\section{International Journal of Business Management and Economic Review}

Vol. 4, No. 04; 2021

ISSN: 2581-4664

performance with work productivity as a mediating variable. As has been defined by many experts, leadership effectiveness is the ability of leaders to influence others so that they contribute to achieving the goals of an organization. The effectiveness of leadership also depends on the pattern of relationships constructed by the leader, while the work environment is a place where every worker spends his daily time carrying out his duties. A conducive work environment will determine the work output produced.

\section{LITERATURE REVIEW \\ Organizational Performance}

The concept of performance can be defined as the level of achievement of results. Performance is a result (output) of a certain process carried out by all components of the organization against certain sources used (input)(Nofriansyah, 2018). According to(Thoyibatun, 2012)Performance is often defined as appearance, demonstration, or achievement. Performance is the level of achievement of organizational goals on an ongoing basis. An organization is said to be high-performing if the organization is able to produce the planned performance on quality improvement by utilizing great human resources. The organizational performance consists of the results obtained compared to work targets(MBN, 2019).

According to(Sinaga \& Sinambela, 2013)Organizational performance is defined as the effectiveness of the organization as a whole to meet the defined needs of each concerned group through systematic efforts and continuously improve the organization's ability to achieve its needs effectively. Organizational performance can also be said to be an organization that is able to achieve targets effectively and efficiently by utilizing its resources and organizational success illustrates a high return on equity caused by the formation of good organizational management.

According to (Moeheriono, 2014)Organizational performance is a reflection of the level of ability to achieve expectations in carrying out something related to activity planning and provisions for designing and achieving organizational targets which are packaged in the form of good progress in the organization. In formulating performance, organizations must consider three important components, namely: objectives, measures, and assessments. Determining the goals of each organizational unit is a strategy to improve performance. This goal will give direction and influence how the work behavior that the organization expects of each person should be. Organizational performance questions the suitability of the organization's mission and goals with the facts of existing economic, cultural, and political conditions or factors.

\section{Work productivity}

Productivity, in general, can be interpreted as the relationship between tangible and physical results (goods or services) with actual inputs(Cascio, 2006). (Robbins \& Judge, 2014)explained that employee work productivity is a performance measure that includes the effectiveness and efficiency of an employee, effectiveness is the achievement of general goals while efficiency is a comparison between effective outputs and the inputs needed to achieve them.(Riadi, 2019)explained that work productivity is a measure of the comparison of the quality and quantity of a workforce in a unit of time to achieve work results or performance effectively and efficiently with the resources used

The State Civil Apparatus (ASN) as the main element of human resources of the state apparatus has a role that determines the success of governance and development. As one of the 


\section{International Journal of Business Management and Economic Review}

Vol. 4, No. 04; 2021

ISSN: 2581-4664

most important components, the professionalism of ASN is often questioned. The role, function, and position of ASN will determine the success or failure of the government's development program. So it is necessary to improve the ability of ASN in order to achieve high work productivity. Because basically every organizational activity that is held to achieve certain goals by organizing these activities is called productivity. An employee can be said to be productive if he is able to produce goods or services as expected in a short or appropriate time(Ardiansyah, 2018).

Organizational performance can increase if employees in the company have high work productivity, this can be seen from the indicators of work productivity variables (work achievement, increasing work quantity, improving work quality, adequate working time, accuracy in work, utilization of facilities, and equipment). company infrastructure, time utilization for work) is statistically proven to have a contribution in improving organizational performance(Mariska, Musnadi, \& Faisal, 2019). Employee work productivity is a comparison of the effectiveness of the output produced by an employee with the efficiency of the input used by an employee which includes quantity and quality within a certain period.

\section{Leadership Effectiveness}

Leadership in an organization is an important factor in determining the achievement of goals set by the organization. Leaders are people who have responsibility for making decisions, carrying out policy directions, supervising, motivators, communicators, and directing their subordinates in running an organization so that they can achieve the goals and objectives of the organization(Zainal, Hadad, \& Ramly, 2019).Effectiveness is the compatibility between the person carrying out the task with the seven objectives. Effectiveness is how an organization succeeds in obtaining and utilizing business resources to realize operational goals(Mulyasa, 2007).

Effective leaders are people with high motivation in leading and controlling the organization, effective leaders will voluntarily try to achieve high goals and targets by setting high standards of achievement for themselves(Mardalena, 2017).Several factors and supporting aspects are needed to become an effective leader. This starts with the leader himself. This is related to ability, personality, and motivation. Then the attitude of the leadership is also an important aspect, both task-oriented, individual, and transformative leadership. It doesn't stop there, being an effective leader requires support from members, both in the form of trust, superior authority, and a structured and clear division of tasks.

The effectiveness of leadership is more concerned with the final results or outputs achieved so that if the final results are not in accordance with the initial goals and there is no desired impact on reality, it is certain that there is no effectiveness value in it(Firdausih, 2018). The leader is required to have a good work plan, then he implements the design in the form of good interactions too, in order to achieve effectiveness(Mardalena, 2017).

\section{Work environment}

The work environment is where workers carry out their activities. The work environment can have a positive or negative impact on employees in carrying out their work(Dwinguspana, Sumari, \& Prihantoro, 2016). A conducive work environment can also be caused by internal and external factors. The work environment will more or less affect the physical and psychological 
Vol. 4, No. 04; 2021

ISSN: 2581-4664

employees when doing their jobs. Therefore, it is very important for leaders to create a work environment that can make their employees work efficiently and effectively and minimize the possibility of employees getting injured while doing their jobs.

The condition of the work environment is said to be good or appropriate if humans can carry out their activities optimally, healthy, safe and comfortable. Inconsistency in the work environment can be seen as a result in the long term. Furthermore, unfavorable environmental activities can demand more energy and time and do not support obtaining an efficient work system design(Plangiten, 2013).

\section{Research Model and Hypothesis}

This research model will explain the relationship between each variable to the improvement of work discipline can be described as follows :

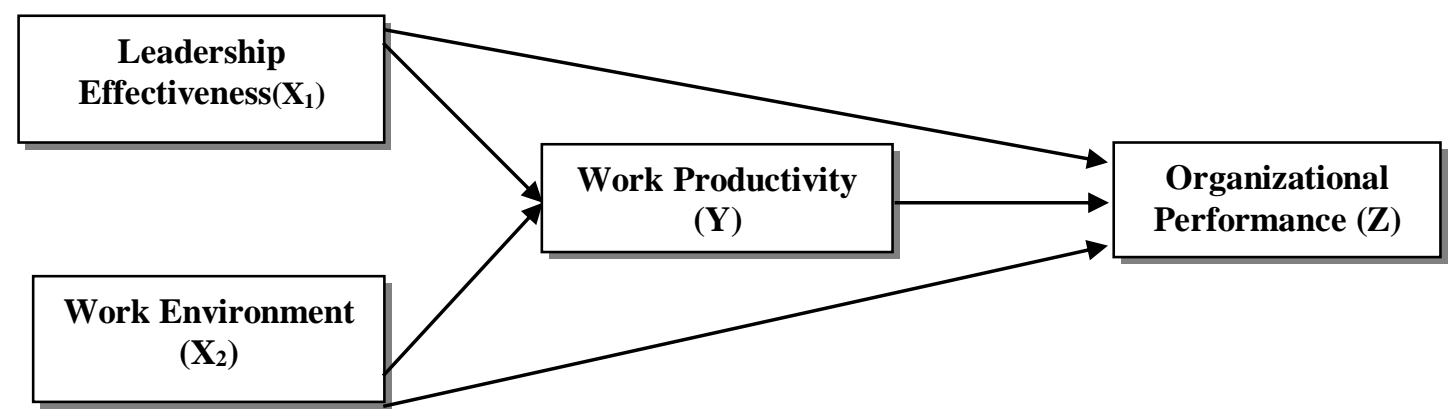

Figure 1. Research Model

Ha1 : Effectiveness of Leadership, Work Environment, Work Productivity and Performance of Disperindagkop Pidie Jaya are good.

Ha2 : Leadership Effectiveness significantly influences Work Productivity of Pidie jaya Disperindagkop employees .

Ha3 : The work environment significantly influencesWork Productivity of Pidie Jaya Disperindagkop Employees.

Ha4 : Leadership Effectiveness significantly influencesOrganizational Performance of Pidie Jaya Disperindagkop.

Ha5 : Work Environment significantly influencesOrganizational Performance of Pidie Jaya Disperindagkop.

Ha6 : Work productivity significantly influencesorganizational performance of Pidie Jaya Disperindagkop.

Ha7 : Leadership Effectiveness significantly influencesOrganizational Performance through Work Productivity of Pidie Jaya Disperindagkop Employees.

Ha8: Work Environment significantly influencesOrganizational Performance through Work Productivity of Pidie Jaya Disperindagkop Employees.

\section{Method}

This research was conducted at the Department of Industry, Trade, Cooperatives, and 


\section{International Journal of Business Management and Economic Review}

Vol. 4, No. 04; 2021

ISSN: 2581-4664

Small and Medium Enterprises of Pidie Jaya Regency (Pidie Jaya Disperindagkop). The research variableswere Leadership Effectiveness, Work Environment, Work Productivity, and Organizational Performance. In this study, the population is all employees at Pidie Jaya Disperindagkop Department, totaling 84 employees, so the method used in this study was the census method, because the population was relatively small.

The study used questionnaires as the data collection technique.Data collection was done by asking a list of questions in writing to the respondents, namely questions related to the variables studied, to make it easier for respondents to answer the questions in the questionnaire with the perception of each respondent. The variable measurement scale used in this study used a Likert scale which functions to measure variable indicators that produce ordinal data. The measurement of variables in this study uses the following indicators:.

1. Organizational performance is measured by indicators as disclosed by(Thoyibatun, 2012)namely (1) input, (2) output, (3) outcome, (4) benefit, (5) impact.

2. Work productivity is measured using indicators as safely disclosed by(Sedarmayanti, 2016)namely (1) work achievement, (2) increasing the quantity of work, (3) improving the quality of work, (4) adequate working time, (5) accuracy in work, (6) utilization of company advice and infrastructure, and (7) utilization of time for work.

3. The effectiveness of leadership is measured using indicators as disclosed by(Mardalena, 2017)namely (1) job satisfaction, (2) work productivity, (3) work quality, (4) efficiency, (5) flexibility, (6) competitiveness, (7) development.

4. The work environment is measured using indicators as disclosed by(Handoko, 2003)in(Rafiie, Azis, \& Idris, 2018)namely (1) lighting/light in the workplace, (2) temperature at work, (3) humidity in the workplace, (4) air circulation in the workplace, (5) noise in the workplace, (6) odors at work, (7) color at work, (8) decoration at work, (9) music at work, (10) safety at work.

This study tested the descriptive hypothesis using a one-sample test with SPSS software. For testing the verification hypothesis, this study used Partial Least Square(PLS) method. PLS is a multivariate data analysis technique that combines the outer model which aims to determine the specification of the relationship between latent variables and their indicators and the inner model which aims to determine the specification of the relationship between latent variables.(Hair, Babin, Anderson, \& Black, 2018).

\section{RESULT}

\section{Descriptive Hypothesis (H1)}

From the results of respondents' perceptions of each variable in this study as shown in table 1 below

Table 1. Recap of Respondents' Perceptions of Variables

\begin{tabular}{|l|l|l|l|l|}
\hline No & Variable & Average & Cut-off & Information \\
\hline 1 & Organizational Performance (Z) & 3.85 & \multirow{2}{*}{3.41} & Good \\
\cline { 1 - 2 } 2 & Work Productivity(Y) & 3.90 & & Good \\
\hline
\end{tabular}




\section{International Journal of Business Management and Economic Review}

Vol. 4, No. 04; 2021

ISSN: $2581-4664$

\begin{tabular}{|l|l|l|l|l|}
\hline \hline 3 & Leadership Effectiveness (X1) & 3.88 & & Good \\
\hline 4 & Work environment (X2) & 3.75 & & Good \\
\hline
\end{tabular}

Source: Processed data (2021)

Based on the data in table 4.16, shows that respondents' perceptions of all variables in this study are in good condition where all these variables have obtained an average value greater than 3.41. The next step is statistical testing using a one-sample T-test using a significant value $(\alpha=$ $5 \%$ ) and a cut-off value of 3.41. The criterion of this test is that if the significant value of the test is greater than 0.05 then the results of the descriptive hypothesis testing are $\mathrm{H} 0$ accepted and $\mathrm{Ha}$ rejected. Likewise, if the test results show a significant value less than 0.05 , then $\mathrm{H} 0$ is accepted and $\mathrm{Ha}$ is rejected. The following table shows the results of the one-sample test.

\section{Table 2. Testing The One-Sample T-Test}

\section{One-Sample Test}

\begin{tabular}{|l|l|l|l|l|l|l|}
\hline \multirow{2}{*}{} & \multicolumn{2}{|l|}{ Test Value $=3.41$} \\
\cline { 2 - 7 } & $\mathrm{t}$ & $\mathrm{df}$ & $\begin{array}{l}\text { Sig. } \\
(2- \\
\text { tailed })\end{array}$ & $\begin{array}{l}\text { Mean } \\
\text { Difference }\end{array}$ & $\begin{array}{l}\text { 95\% Confidence Interval of } \\
\text { the Difference }\end{array}$ \\
\cline { 3 - 7 } & 5.555 & 83 & .000 & .47262 & .3034 & .6418 \\
\hline Leadership Effectiveness & 4.087 & 83 & .000 & .33762 & .1733 & .5019 \\
\hline Work environment & 5.309 & 83 & .000 & .48976 & .3063 & .6733 \\
\hline Work Productivity & 4.675 & 83 & .000 & .43524 & .2501 & .6204 \\
\hline Organizational Performance & \multicolumn{7}{l}{} \\
\hline
\end{tabular}

Source: Processed data (2021)

The results of the one-sample $t$-test with test value $=3.41$ as shown in Table 4.17 above, it is known that all variables show sig values. (2-tailed) of $0.000<0.05$. With this, it can be concluded that the results of the descriptive hypothesis testing (H1) are accepted where $\mathrm{Ha}$ is accepted and Ho is rejected. These results can be interpreted that the effectiveness of leadership, work environment, work productivity, and organizational performance in this study are in good conditions.

\section{Direct Hypothesis Testing (H2, H3, H4, H5, and H6)}

The results of the full PLS model analysis are shown in Figure 2 below 


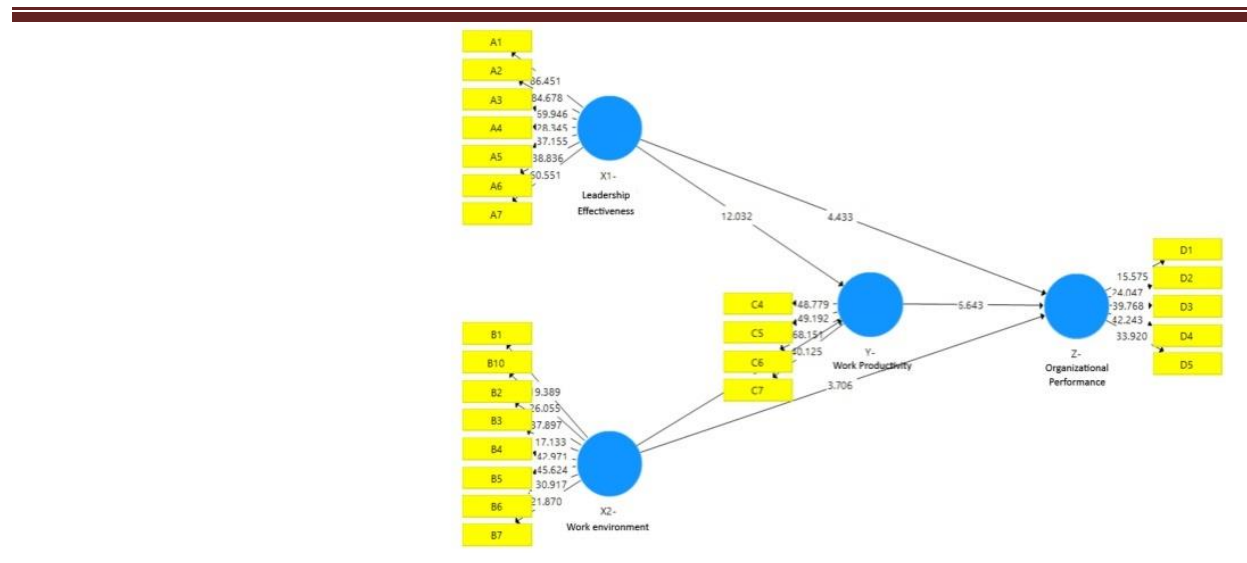

Figure 2. Test Results of PLS Model

Based on the test results above, it can be explained that the influence of each variable is leadership effectiveness, work environment, work productivity, and organizational performance. The magnitude of the influence of each variable is as shown in table 3 below:

Table 3. Results of Direct Effect Path

\begin{tabular}{|l|l|l|l|l|l|}
\hline Inter-Variable & $\begin{array}{l}\text { Original } \\
\text { Sample } \\
(\mathbf{O})\end{array}$ & $\begin{array}{l}\text { Sample } \\
\text { Mean } \\
(\mathbf{M})\end{array}$ & $\begin{array}{l}\text { Standard } \\
\text { Deviation }\end{array}$ & $\begin{array}{l}\text { T } \\
\text { Statistics }\end{array}$ & P Values \\
\hline $\begin{array}{l}\text { X1_Leadership Effectiveness - } \\
\text { >Y_Work Productivity }\end{array}$ & 0.666 & 0.659 & 0.055 & 12.032 & 0.000 \\
\hline $\begin{array}{l}\text { X1_Leadership Effectiveness - } \\
\text { >Z_Organizational Performance }\end{array}$ & 0.471 & 0.466 & 0.106 & 4.433 & 0.000 \\
\hline $\begin{array}{l}\text { X2_Work environment - } \\
\text { >Y_Work Productivity }\end{array}$ & 0.309 & 0.317 & 0.059 & 5.278 & 0.000 \\
\hline $\begin{array}{l}\text { X__Work environment ->Z_ } \\
\text { Organizational Performance }\end{array}$ & 0.260 & 0.253 & 0.127 & 3.706 & 0.000 \\
\hline $\begin{array}{l}\text { Y_Produktivitas kerja-> Z_ } \\
\text { Organizational Performance }\end{array}$ & 0.553 & 0.554 & 0.083 & 6.643 & 0.000 \\
\hline
\end{tabular}

Source: Primary data, 2021 (processed) as follows:

By looking at the test results above, the results of direct hypothesis testing can be explained

Leadership Effectiveness Affecting Work Productivity of Pidie Jaya Disperindagkop (H2)

The results of testing hypothesis 2 , namely the influence of leadership effectiveness on work productivity of Disperindagkop Pidie Jaya employees, obtained a path coefficient value of 0.666 . The T statistic value is $12.032>1.96$ and the P-Value value is $0.000<0.05$. This value indicates that the effectiveness of leadership has a positive and significant influence on the work productivity of Disperindagkop Pidie Jaya employees. The direct influence of leadership 


\section{International Journal of Business Management and Economic Review}

Vol. 4, No. 04; 2021

ISSN: 2581-4664

effectiveness on the work productivity of Disperindagkop Pidie Jaya employees is 0.666 or $66.6 \%$. These results indicate that the results of testing Hypothesis 2 are $\mathrm{Ha} 2$ accepted and $\mathrm{H} 02$ rejected. The results of this study are in line with the results of research conducted by(Makambe \& Moeng, 2020), (Shafiu, Manaf, \& Muslim, 2019), (Radwan, 2018), (Goren, 2018), (Subardjono, 2017), (Madaan, 2015), (Sarjana, 2012)which they also prove that leadership effectiveness has a positive impact on work productivity.

Based on respondents' responses to leadership effectiveness, what is the leader's full concern to continue to be effective is flexibility where a flexible leader will have the potential to be effective in some situations so that the quality of work, quantity of work, and efficiency of working time will continue to increase Furthermore, in an effort to increase productivity, leaders must always be oriented to the achievements that have been made so far. By being oriented towards this achievement, employee productivity will continue to be improved for the better. Next is the participation of leaders where participation will be able to increase the chances of satisfaction for its employees. Participation in question is an effort to help each employee in achieving work goals, helping to reduce obstacles that become obstacles for his employees and rewarding the achievements that have been made by his employees.

\section{Work Environment Affecting Work Productivity of Disperindagkop Pidie Jaya (H3)}

Based on the results of testing hypothesis 3 , namely the influence of the work environment on the work productivity of Disperindagkop Pidie Jaya employees, the path coefficient value is 0.309. The statistical $\mathrm{T}$ value is $5.278>1.96$ and the $\mathrm{P}$-Value is $0.000<0.05$. This value indicates that the work environment has a positive and significant influence on the work productivity of the Disperindagkop Pidie Jaya employees. Based on the value of the original sample, it can be seen that the direct influence of the work environment on the work productivity of Disperindagkop Pidie Jaya employees is $30.9 \%$. These results indicate that the results of testing Hypothesis 3 are $\mathrm{Ha} 3$ accepted and $\mathrm{H} 03$ rejected. The results of this study are in line with the results of research conducted by(Fitri, Musnadi, \& Syafruddin, 2020), (Mariska et al., 2019), (Ihya, Adam, \& Nurdin, 2019)where they also prove that the work environment affects employee productivity.

These results conclude that the more conducive the work environment at Disperindagkop Pidie Jaya, the better the work productivity produced by its employees. A work environment is a daily place for employees to carry out their duties in running the wheels of government and providing services to the community as servants of the state. Based on field observations, the Pidie Jaya Disperindagkop leader must always pay attention to the conditions of the work environment, both the physical work environment and the non-physical work environment. Because with a conducive work environment, it will provide a sense of security and comfort for employees in carrying out their daily tasks. For the physical work environment, the leader of Disperindagkop Pidie Jaya must always pay attention to and maintain all the facilities it has, especially facilities such as computers/laptops, internet facilities, air conditioning facilities, and parking facilities.

Leadership Effectiveness Affecting the Performance of the Pidie Jaya Disperindagkop (H4)

Testing hypothesis 4 , the effect of leadership effectiveness on the performance of Disperindagkop Pidie Jaya obtained a path coefficient value of 0.471 . The T statistic value is 


\section{International Journal of Business Management and Economic Review}

Vol. 4, No. 04; 2021

ISSN: 2581-4664

$4.433>1.96$ and the P-Value value is $0.000<0.05$. This value indicates that the effectiveness of leadership has a positive and significant influence on the performance of the Disperindagkop Pidie Jaya. Based on the value of the original sample, it can be seen that the direct influence of leadership effectiveness on the performance of Disperindagkop Pidie Jaya is $47.1 \%$. These results indicate that the results of testing Hypothesis 4 are $\mathrm{Ha} 4$ accepted and $\mathrm{H} 04$ rejected. The results of this study are in line with the results of research conducted by(Mariana, Musnadi, \& Kesuma, 2020), (Hamzali, Hafasnuddin, Bahri, \& Nurhalis, 2020), (Muslim, Bahri, \& Ibrahim, 2020), (Catio, 2020), (Suwaji, 2019), (Astuti \& Prayogi, 2018), (Rasmuji \& Putranti, 2017), (Zarvedi, Yusuf, \& Ibrahim, 2016)where they also prove that leadership effectiveness has a significant effect on organizational performance.

The results of this study can be concluded that the better the effectiveness of the leadership, the better the performance of the Disperindagkop produced. Good organizational performance is formed because of the underlying factors, one of which is the effectiveness of leadership in leading the organization. A leader who has leadership effectiveness will have the ability to solve problems and have good relationships with subordinates. (Madanchian, Hussein, Noordi, \& Taherdoos, 2016)stated that effective leadership is very important in the organization and is able to affect the performance (outcome) of the organization.

Based on the results of field observations, to be able to continue to improve organizational performance, leaders must always participate in various fields of work being planned and implemented so that any problems or obstacles that occur can be immediately overcome and improvements in work quality, work quantity, work time efficiency can be maintained and can be further improved. The Pidie Jaya Disperindagkop leader must continue to campaign for the existence of his organization and its organizational functions to the community so that the existence and functions of this organization can be realized directly by the community in growing their economy.

Work Environment Affecting the Performance of the Pidie Jaya Disperindagkop (H5)

Testing hypothesis 5 about the influence of the work environment on the performance of the Disperindagkop Pidie Jaya obtained a path coefficient value of 0.260 . The value of T statistic is $3.706<1.96$ and the value of P-Value is $0.000>0.05$. This value indicates that the work environment has a positive and significant influence on the performance of the Disperindagkop Pidie Jaya. Based on the value of the original sample, it can be seen that the direct influence of the work environment on the performance of Disperindagkop Pidie Jaya is $26.0 \%$. These results indicate that the results of testing Hypothesis 5 are Ha5 accepted and $\mathrm{H} 05$ rejected. The results of this study are in line with the results of research conducted by(Fajriyati, Adam, \& Musnadi, 2020), (Fitri et al., 2020), (Ihya et al., 2019), (Fachreza, Musnadi, \& Shabri, 2018), (Chandrasekar, 2011) where the results of their research also prove that the work environment has a positive impact on organizational performance.

The results of this study can be concluded that the better the work environment owned by Disperindagkop Pidie Jaya, the better the resulting organizational performance. As stated in contingency theory, it is stated that to maximize the performance area, it can be done by paying attention to organizational environmental factors(Anwar, 2015). A good organizational environment will make employees feel comfortable in carrying out their work. This convenience will encourage every worker to increase their productivity and overall performance. 


\section{International Journal of Business Management and Economic Review}

Vol. 4, No. 04; 2021

ISSN: 2581-4664

Based on the results of field observations, the work facilities owned by Disperindagkop Pidie Jaya in supporting the work of each employee need to be further improved so that the specifications of the equipment such as computers can support the work of each employee so that in the end it will also have a good impact on the performance of Disperindagkop. In addition to equipment such as computers, documentation equipment also needs to be further improved, especially with equipment that has a large memory capacity so that documentation taken from the field is not lost or wasted. In addition to the physical work environment that must be improved, the leaders also have a non-physical work environment in the Disperindagkop Pidie Jaya such as working relationships between employees must always maintain harmony.

\section{Work Productivity Affecting the Performance of Pidie Jaya Disperindagkop(H6)}

The results of testing hypothesis 6 about the effect of employee work productivity on the performance of Disperindagkop Pidie Jaya obtained a path coefficient value of 0.553 . The statistical $\mathrm{T}$ value is $6.643>1.96$ and the $\mathrm{P}$-Value is $0.000<0.05$. This value indicates that employee work productivity has a positive and significant impact on the performance of the Disperindagkop Pidie Jaya. Based on the original sample value, it can be seen that the direct effect of employee productivity on the performance of the Pidie Jaya Disperindagkop is 55.3\%. These results indicate that the results of testing Hypothesis 6 are Ha6 accepted and H06 rejected. The results of this study are in line with the results of research conducted by(Ihya et al., 2019), (Mariska et al., 2019)where they also prove that productivity has a positive impact on organizational performance.

Based on field observations, although the results of respondents' responses to work productivity and organizational performance are good, departmental leaders must always strive to continue to improve the results of these two variables. In an effort to increase work productivity, departmental leaders must always be able to improve points such as achieving work targets, improving work quality, work quantity, work accuracy, and working time. Service leaders must conduct periodic performance evaluations of their employees so that the work progress of each employee can be known and the obstacles faced by employees can be immediately identified and determine the solution to these obstacles. In addition, departmental leaders must give awards to employees who have the highest work productivity so that they can trigger other employees to increase their work productivity. This needs to be done because achieving good organizational performance, depends on the work productivity of its employees.

\section{Indirect Effect Hypothesis Testing (H7 and H8)}

Testing the mediation or indirect hypothesis is done using a hierarchical regression model. This approach is used to identify the mediating effect of the model that has been built. A mediator is seen as the third variable that influences and is also influenced by the independent variable. The results of indirect hypothesis testing in this study are as shown in the following table 
International Journal of Business Management and Economic Review

Vol. 4, No. 04; 2021

ISSN: 2581-4664

Table 4. Results of Indirect Effect Path

\begin{tabular}{|ll|l|l|l|l|l|}
\hline Inter-Variable & & $\begin{array}{l}\text { Original } \\
\text { Sample (O) }\end{array}$ & $\begin{array}{l}\text { Sample } \\
\text { Mean } \\
(\mathbf{M})\end{array}$ & $\begin{array}{l}\text { Standard } \\
\text { Deviation }\end{array}$ & $\begin{array}{l}\text { T } \\
\text { Statistics }\end{array}$ & P Values \\
\hline $\begin{array}{l}\text { X1_leadership effectiveness } \\
\text { Y_Work Productivity -> }\end{array}$ & $\begin{array}{l}\text { Z_W } \\
\text { Organizational Performance }\end{array}$ & 0.368 & 0.364 & 0.058 & 6.385 & 0.000 \\
\hline $\begin{array}{l}\text { X2_Work Enveronment-> Y-W Y-> } \\
\text { Work Productivity } \\
\text { Z_Organizational Performance }\end{array}$ & 0.171 & 0.177 & 0.046 & 3.447 & 0.000 \\
\hline
\end{tabular}

Source: Processed Data (2021)

Leadership Effectiveness Affecting the Performance of Disperindagkop Pidie Jaya through Work Productivity (H7)

The results of testing hypothesis 7 regarding the effect of Leadership Effectiveness on the Performance of Disperindagkop Pidie Jaya through Work Productivity as shown in table 4.18 above obtain a path coefficient value of 0.368 . The T statistic value is $6.385>1.96$ and the $\mathrm{P}$ Value value is $0.000<0.05$. These results indicate that hypothesis testing 7 is accepted where $\mathrm{Ha} 7$ is accepted and $\mathrm{H} 07$ is rejected. So this proves that work productivity mediates the effect of leadership effectiveness on the performance of Disperindagkop Pidie Jaya. Based on the significant calculation for path $\mathrm{C}^{\prime}$, the significant values for all paths (A, B, C, and $\left.\mathrm{C}^{\prime}\right)$ are shown in Figure 3 below.

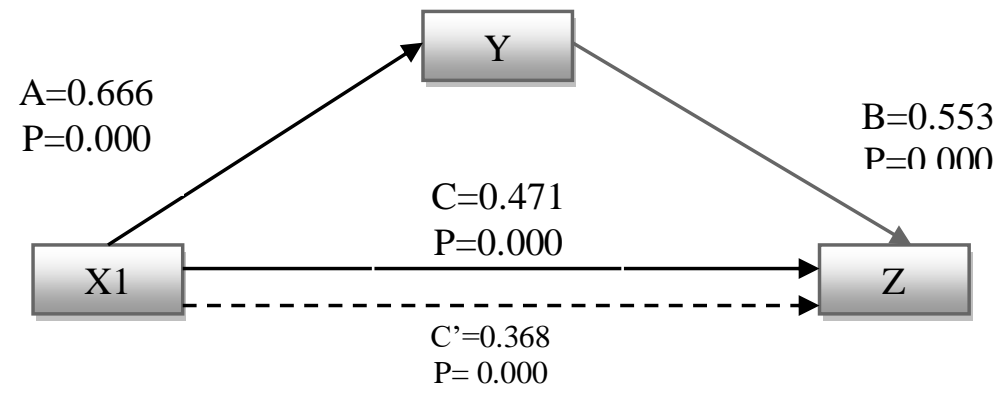

Figure 3. Hypothesis 7 Testing

From the picture above, it can be explained that the path coefficient $\mathrm{A}$ has a value of $=$ 0.666 and a value of $p=0.000<0.05$. Path $B$ has a value of $=0.553$ and a value of $p=0.000<$ 0.05 . From the values of paths $\mathrm{A}$ and $\mathrm{B}$, it can be concluded that they are significant, while path $\mathrm{C}$ has a value of $=0.471$ and a value of $p=0.000<0.05$ and $C^{\prime}$ has a value of $=0.368(0.666 \mathrm{x}$ $0.553=0.368$ ) and a value of $p=0.000<0,05$. This value indicates that paths $A, B, C$, and $C^{\prime}$ are significant or often referred to as partial mediation. The magnitude of the mediating role of work productivity on the influence of leadership effectiveness on the performance of the Disperindagkop Pidie Jaya is 0.368 or $36.8 \%$ 


\section{International Journal of Business Management and Economic Review}

Vol. 4, No. 04; 2021

ISSN: 2581-4664

Work Environment Affecting the Performance of Disperindagkop Pidie Jaya through Work Productivity (H8)

The results of testing hypothesis 8 regarding the influence of the work environment on the performance of the Disperindagkop Pidie Jaya through work productivity as shown in table 4.18 above obtain a path coefficient value of 0.171 . The T statistic value is $3.447>1.96$ and the PValue is $0.001<0.05$. These results indicate that hypothesis testing 8 is accepted where Ha8 is accepted and $\mathrm{H} 08$ is rejected. So it is hereby proved that work productivity mediates the effect of the work environment on the performance of Disperindagkop Pidie Jaya. Based on the significant calculation for path $\mathrm{C}^{\prime}$, the significant values for all paths (A, B, C, and $\left.\mathrm{C}^{\prime}\right)$ are shown in Figure 4 below.

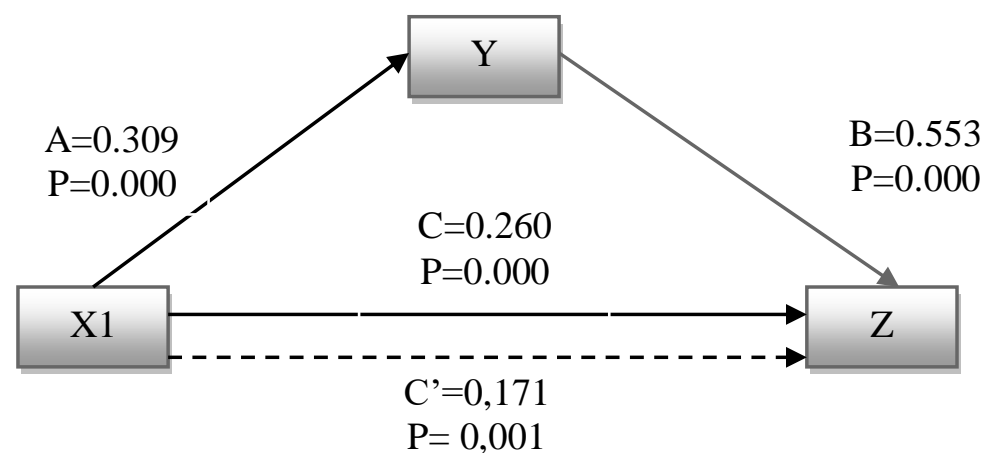

Figure 4. Hypothesis 8 Testing

From the picture above, it can be explained that the path coefficient $\mathrm{A}$ has a value of $=$ 0.309 and a value of $p=0.000<0.05$. Path $B$ has a value of $=0.553$ and a value of $p=0.000<$ 0.05 . From the values of paths $\mathrm{A}$ and $\mathrm{B}$, it can be concluded that they are significant, while path $C$ has a value of $=0.260$ and a value of $p=0.000<0.05$ and $C^{\prime}$ has a value of $=0.171(0.309 x$ $0.553=0.171$ ) and a value of $\mathrm{p}=0.001<0,05$. This value indicates that paths $\mathrm{A}, \mathrm{B}, \mathrm{C}$, and $\mathrm{C}^{\prime}$ are significant or often referred to as partial mediation. The magnitude of the mediating role of work productivity on the influence of the work environment on the performance of the Disperindagkop Pidie Jaya is 0.171 or $17.1 \%$

\section{CONCLUSIONS}

From the results of research conducted at Disperindagkop Pidie Jaya, the following conclusions can be drawn:

a. The results of descriptive hypothesis testing, namely the effectiveness of leadership, work environment, work productivity, and organizational performance have good results. This can be seen from the overall average value of respondents' perceptions of the research variables is $3.81>3.41$. By using a one-sample test with a cut-off value of 3.41 where the results obtained the provability value on all variables is $0.000<0.05$.

b. The results of testing the direct effect hypothesis (direct path)are known that leadership effectiveness has a significant influence on work productivity, the work environment has a significant influence on work productivity, leadership effectiveness has a significant influence on organizational performance, the work environment has a significant influence 
International Journal of Business Management and Economic Review

Vol. 4, No. 04; 2021

ISSN: 2581-4664

on organizational performance, and work productivity has a significant influence on work productivity on organizational performance.

c. The results of testing the indirect effect hypothesis (indirect path) show that work productivity mediates partially (partial mediation) the effect of leadership effectiveness on organizational performance, and work productivity partially mediates (partial mediation) the effect of the work environment on organizational performance.

Some recommendations can be give based on the analysis results.

1. To improve organizational performance, leaders must always participate in various fields of work being planned and implemented so that any problems or obstacles that occur can be immediately overcome and improvements in work quality, work quantity, work time efficiency can be maintained and can be further improved. The Pidie Jaya Disperindagkop leader must continue to campaign for the existence of his organization and its organizational functions to the community so that the existence and functions of this organization can be realized directly by the community in growing their economy.

2. In an effort to increase work productivity, department heads must always be able to improve points such as achieving work targets, improving work quality, work quantity, work accuracy, and working time. Service leaders must conduct periodic performance evaluations of their employees so that the work progress of each employee can be known and the obstacles faced by employees can be immediately identified and determine the solution to these obstacles. In addition, departmental leaders must give awards to employees who have the highest work productivity so that they can trigger other employees to increase their work productivity. This needs to be done because achieve good organizational performance, depends on the work productivity of its employees.

3. Leadership effectiveness, which is the leader's full concern to continue to be effective is flexibility where a flexible leader will have the potential to be effective in some situations so that the quality of work, quantity of work, and efficiency of working time will continue to increase. Furthermore, in an effort to increase productivity, leaders must always be oriented to the achievements that have been made so far. By being oriented towards this achievement, employee productivity will continue to be improved for the better. Next is the participation of leaders where participation will be able to increase the chances of satisfaction for its employees. Participation in question is an effort to assist each employee in achieving work goals, helping to reduce obstacles that become obstacles for employees, and rewarding the achievements made by employees. Leaders are also required to be more responsive to changes and developments so that they can better know the needs of their work environment

4. A work environment is a daily place for employees to carry out their duties in carrying out the wheels of government and providing services to the community as servants of the state. Based on field observations, the Pidie Jaya Disperindagkop leader must always pay attention to the conditions of the work environment, both the physical work environment and the nonphysical work environment. Because with a conducive work environment, it will provide a sense of security and comfort for employees in carrying out their daily tasks. For the physical work environment, the Pidie Jaya Disperindagkop leader must always pay attention to and maintain all the facilities he has, especially facilities such as computers/laptops, internet facilities, air conditioning facilities, and parking facilities. the work facilities owned 


\section{International Journal of Business Management and Economic Review}

Vol. 4, No. 04; 2021

ISSN: 2581-4664

by the Pidie Jaya Disperindagkop in supporting the work of each employee need to be further improved so that the specifications of the equipment such as computers can support the work of each employee's work so that in the end it will also have a good impact on the performance of the Disperindagkop. In addition to equipment such as computers, documentation equipment also needs to be further improved, especially with equipment that has a large memory capacity so that documentation taken from the field is not lost or wasted. In addition to the physical work environment that must be improved, the leaders also have a non-physical work environment in the Disperindagkop Pidie Jaya such as working relationships between employees must always maintain harmony.

5. For further researchers can develop this model by adding other variables such as work performance and innovation that exist in employees in the organization.

\section{REFERENCES}

Abdurrauf, Lubis, A. rahman, \& Chan, S. (2015). Pengaruh Produktivitas Kerja Dan Penegakan Disiplin Terhadap Kinerja Pegawai Serta Dampaknya Terhadap Kinerja Sekretariat Daerah Aceh. Jurnal Management, 4(1), 211-220.

Anwar, M. (2015). Contingency Theory and Its Implications to Corporate Financial Planning and Organization Structure. Jurnal Aplikasi Manajemen, 13(3), 363-370.

Ardiansyah, M. (2018). Produktivitas Aparatur Sipil Negara. Retrieved May 5, 2020, from Academia.edu https://www.academia.edu/36995379/Produktivitas_Aparatur_Sipil_Negara

website:

Astuti, R., \& Prayogi, I. (2018). Pengaruh Kepemimpinan Dan Prestasi Kerja Terhadap Kinerja Karyawan Pada PT. Karya Hevea Indonesia Afdeling Hevea Dolok Masihul. The National Conferences Management and Business (NCMAB) 2018 "Pemberdayaan Dan Penguatan Daya Saing Bisnis Dalam Era Digital,” 490-502. Surakarta: Program Studi Manajemen Fakultas Ekonomi dan Bisnis Universitas Muhammadiyah Surakarta.

Badan-Statistik. (2019). Pidie Jaya Dalam Angka 2019. Kabupaten Pidie Jaya.

Cascio, W. (2006). Managing Human Resources: Productivity, Quality of Work Life, Profits (7th, illustr ed.). New York: McGraw-Hill.

Catio, M. (2020). The Influence of Leadership and Work Environment on Employee Performance at PT. Suksesindo Pratama in Jakarta. Jurnal Ilmiah Ilmu Administrasi Publik, 10(1), 243-252. https://doi.org/https://doi.org/10.26858/jiap.v10i1.14468

Chandrasekar, K. (2011). Workplace environment and its impact on organizational performance in public sector organizations. International Journal of Enterprise Computing and Business Systems, 1(1), 1-19.

Dwinguspana, E., Sumari, A. D. W., \& Prihantoro, M. (2016). Pengaruh Kompensasi terhadap Kedisiplinan dan Kinerja Prajurit Batalyon Kavaleri 11/Serbu Kodam Iskandar Muda. Jurnal Pertahanan, 6(1), 169-191.

Fachreza, Musnadi, S., \& Shabri, M. (2018). Pengaruh motivasi kerja, lingkungan kerja, dan budaya organisasi terhadap kinerja karyawan dan dampaknya pada kinerja bank aceh 


\section{International Journal of Business Management and Economic Review}

Vol. 4, No. 04; 2021

ISSN: 2581-4664

syariah di kota banda aceh. Jurnal Magister Manajemen, 2(1), 115-122.

Fajriyati, Adam, M., \& Musnadi, S. (2020). Determinant Of Organizational Performance Mediated By Job Satisfaction: Study In Department Of Public Works And Spatial Planning Of Aceh Province. International Journal of Business Management and Economic Review, 3(1), 158-168. https://doi.org/ttp://doi.org/10.35409/IJBMER.2020.3147

Firdausih, I. (2018). Efektivitas Kepemimpinan Kepala Daerah Dalam Penyelenggaraan Pembangunan Infrastruktur Di Kabupaten Bangkalan. Kebijakan Dan Manajemen Publik, $6(1), 1-10$.

Fitri, E., Musnadi, S., \& Syafruddin. (2020). The Effect Of Organizational Culture, Work Environment And Incentive On Employee Performance And Its Impact On The Performance Of Banda Aceh Government Health Department. International Journal of Scientific and Management Research, 3(3), 189-198.

Goren, P. (2018). Effect of Leadership Styles on Employee Productivity at South Nyanza Sugar Company Limited, Migori County. International Journal of Progressive Sciences and Technologies, 6(2), 423-427. https://doi.org/http://dx.doi.org/10.52155/ijpsat.v6.2.262

Hair, J. F., Babin, B. J., Anderson, R. E., \& Black, W. C. (2018). Multivariate Data Analysis (8th Ed.). London: Pearson.

Hamzali, S., Hafasnuddin, Bahri, S., \& Nurhalis. (2020). The Influence of Leadership Style and Organizational Learning on Organizational Performance at Syiah Kuala University Library Banda Aceh, Indonesia with Organizational Innovation as a Mediating Variable. East African Scholars Journal of Economics, Business and Management, 3(1), 41-53. https://doi.org/10.36349/easjebm.2020.v03i01.006

Handoko, T. H. (2003). Manajemen edisi 2. Yogyakarta: BPFE.

Humas-Pijay. (2016). Perindustrian, Perdagangan, Koperasi, dan UKM.

Ihya, Adam, M., \& Nurdin, R. (2019). The Influence of Individual Characteristics, Organizational Characteristics and Work Environment on Employee Performance and Its Impact on the Performance of Bkkbn Representative Organization of Aceh Province. International Journal OfBusiness and Social Science, 10(5), 95-107. https://doi.org/10.30845/ijbss.v10n5p10

Indiahono, D. (2017). Kebijakan Publik Berbasis Dynamic Policy Analysis. Yogyakarta: Gava Media.

Kimsean, Y. (2004). Produktivitas Kerja Pegawai pada Birokrasi. Gava Media, Yogyakarta.

Madaan, S. (2015). Impact of Leadership on Employees Productivity. International Journal of Engineering Technology Science and Research, 2(11), 134-138.

Madanchian, M., Hussein, N., Noordi, F., \& Taherdoos, H. (2016). European Business \& Management The Relationship between Ethical Leadership, Leadership Effectiveness and Organizational Performance: A Review of Literature in SMEs Context. European Business \& Management, 2(2), 17-21. https://doi.org/10.11648/j.ebm.20160202.11 


\section{International Journal of Business Management and Economic Review}

Vol. 4, No. 04; 2021

ISSN: 2581-4664

Makambe, U., \& Moeng, G. J. M. (2020). The effects of leadership styles on employee performance: a case of a selected commercial bank in Botswana. Annals of Management and Organization $\quad$ Research, $39-50$. https://doi.org/https://doi.org/10.35912/amor.v1i1.274

Mardalena. (2017). Efektivitas Kepemimpinan: Sebuah Kajian Teoritis. Jurnal Pendidikan STKIP YPM Bangko, 2(1), 1-6.

Mariana, Musnadi, S., \& Kesuma, T. M. (2020). The Effect of Women's Leadership Performance on the Effectiveness of Organization and Its Impact on The Performance of Women's Organization In Aceh Province, Indonesia. East African Scholars Multidisciplinary Bulletin, 3(3), 61-66. https://doi.org/10.36349/easmb.2020.v03i03.001

Mariska, K., Musnadi, S., \& Faisal. (2019). Determinant of Organizational Performance with Work Productivity as A Mediation: Case of PT. Bank Tabungan Negara (BTN) Banda Aceh. East African Scholars Journal of Economics, Business and Management, 2(8), 412415.

MBN. (2019). Organizational performance - definition and meaning. Retrieved May 11, 2020, from Market Business News website: https://marketbusinessnews.com/financialglossary/organizational-performance-definition-meaning/

Moeheriono. (2014). Pengukuran Kinerja Berbasis Kompetensi (Revision). Jakarta: Raja Grafindo Persada.

Mulyasa. (2007). Manajemen Berbasis Sekolah. Bandung: PT. Remaja Rosdakarya.

Muslim, Bahri, S., \& Ibrahim, R. (2020). Analysis of The Effect of Motivation, Leadership and Work Environment on Employee Performance and Its Impact on The Performance of Govermental Working Unit (SKPK) (Case Study at Aceh Jaya District, Aceh Province, Indonesia. East African Scholars Multidisciplinary Bulletin, 3(3), 106-116. https://doi.org/10.36349/easmb.2020.v03i03.007

Nofriansyah, D. (2018). Penelitian Kualitatif: Analisis Kinerja Lembaga Pemberdayaan Masyarakat Kelurahan. Yogyakarta: Deepublish.

Patmarina, H., \& Erisna, N. (2012). Pengaruh Disiplin Kerja Terhadap Kinerja Karyawan Yang Dimediasi Oleh Produktivitas Kerja Perusahaan CV. Laut Selatan Jaya Di Bandar Lampung. Jurnal Manajemen Dan Bisnis, 3(1).

Plangiten, P. (2013). Gaya Kepemimpinan dan Lingkungan Kerja Pengaruhnya terhadap Kepuasan Kerja Karyawan pada PT. Pos Indonesia (Persero) Manado. Jurnal EMBA, 1(4), 2155-2166.

Radwan, M. (2018). The impact of leadership on Employees' Productivity in Jaguar Land Rover Saudi Arabia service center. Jerman Barat: Grin Verlag.

Rafiie, D. S., Azis, N., \& Idris, S. (2018). Pengaruh Kompetensi, Gaya Kepemimpinan, Budaya Kerja, dan Lingkungan Kerja Terhadap Kepuasan Kerja Pegawai dan Dampaknya Terhadap Kinerja Pegawai Kantor Kementerian Agama Kabupaten Aceh Barat. Jurnal Magister Manajemen, 2(1), 36-45. 


\section{International Journal of Business Management and Economic Review}

Vol. 4, No. 04; 2021

ISSN: 2581-4664

Rasmuji, \& Putranti, R. D. (2017). Pengaruh Efektivitas Kepemimpinan Dan Lingkungan Kerja Terhadap Kinerja Karyawan Dengan Peran Mediasi Kepuasan Kerja (Studi pada PD. BPR BKK Batang). Media Ekonomi Dan Manajemen, 32(2), 178-194.

Riadi, M. (2019). Produktivitas Kerja - Pengertian, Aspek dan Pengukuran. Retrieved May 22, 2020, from https://www.kajianpustaka.com/ website: https://www.kajianpustaka.com/2019/11/produktivitas-kerja-pengertian-aspek-pengukurandan-faktor-yang-mempengaruhi.html

Robbins, S. P., \& Judge, T. A. (2014). Buku Perilaku Organisasi Buku 2 (Edisi ke-1; alih bahasa D. Angelica, Ed.). Salemba Empat.

Romat. (2010). Kepemimpinan Pendidikan: Konsep dan Aplikasi. Purwokerto: STAIN Press.

Sarjana, S. (2012). Pengaruh Motivasi dan Efektivitas Kepemimpinan Terhadap Produktivitas. Jurnal Perkotaan, 4(2), 88-101.

Sedarmayanti. (2016). Manajemen sumber daya manusia reformasi birokrasi dan manajemen pegawai negeri sipil (5th ed.). Bandung: Repika Aditama.

Shafiu, A. M., Manaf, H. A., \& Muslim, S. (2019). The Impact Of Effective Leadership On Employee's Performance In Local Government Of Kaduna State, 2013-2019. The International Journal of Engineering and Science (IJES), 8(11), 60-65. https://doi.org/10.9790/1813-0811026065

Sinaga, T., \& Sinambela, M. (2013). Pengaruh Stres Kerja Terhadap Motivasi Dan Kinerja Auditor Pada Kantor Akuntan Publik Di Kota Medan. Jurnal Akuntansi, XVII(1), 75-83.

Subardjono. (2017). Pengaruh Kepemimpinan Terhadap Produktivitas Kerja Pegawai Pada Dinas Pendidikan Nasional (Disdiknas) Dan Kebudayaan Kabupaten Oku Timur. Jurnal Aktual STIE Trisna Negara, 15(1), 1-9. Retrieved from 10.47232/aktual.v15i1.8

Suwaji, R. (2019). Pengaruh Motivasi Kerja, Kepemimpinan Dan Budaya Organisasi Terhadap Kepuasan Kinerja Karyawan Serta Dampaknya Pada Kinerja Perusahaan. MAPAN: Jurnal Manajemen Akuntansi Palapa Nusantara, 4(1), 48-54.

Thoyibatun, S. (2012). Faktor-Faktor Yang Berpengaruh Terhadap Perilaku Tidak Etis Dan Kecenderungan Kecurangan Akuntansi Serta Akibatnya Terhadap Kinerja Organisasi. EKUITAS (Jurnal Ekonomi Dan Keuangan), 16(2), 245-260.

Zainal, V. R., Hadad, M. D., \& Ramly, M. (2019). Kepemimpinan dan Perilaku Organisasi (4 Ed). Depok: Raja Grafindo Persada.

Zarvedi, R., Yusuf, R., \& Ibrahim, M. (2016). Pengaruh Kepemimpinan, Budaya Organisasi dan Kompetensi Terhadap Kinerja Pegawai Serta Implikasinya Pada Kinerja Sekretariat Kabupaten Pidie Jaya. Jurnal Perspektif Ekonomi Darussalam, 2(2), 201-217. Retrieved from www.jurnal.unsyiah.ac.id/JPED 